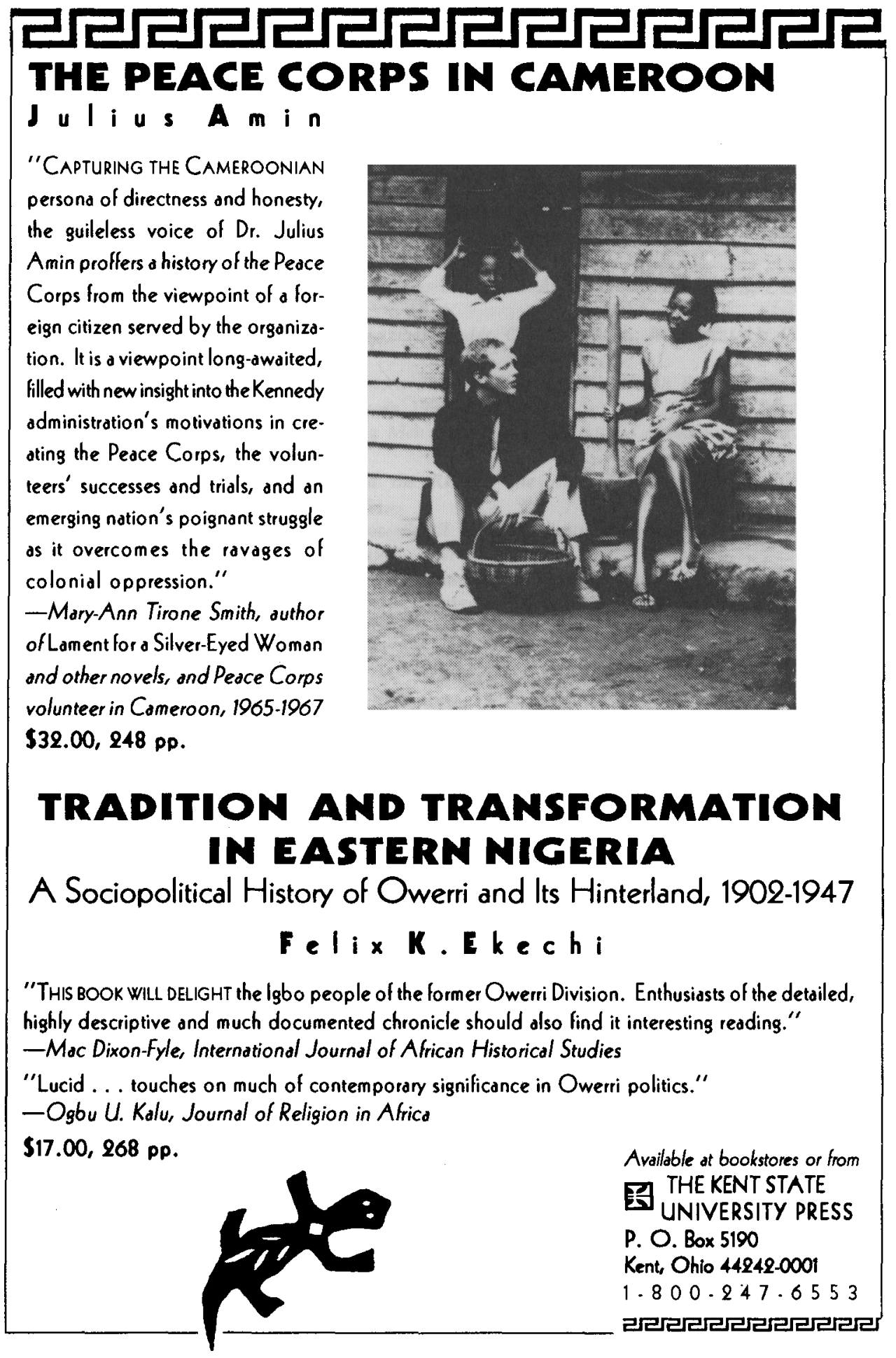




\section{ARICA-THE LAN and}

JUMP AND OTHER STORIES

\section{Nadine Gordimer}

This latest collection of 16 stories fom Nobel Prize winner Gordimer travels to places as distant as suburban London, Mozambique, and South Africa, forming a portrait of life as it is lived now, at the end of the 20th century. $272 \mathrm{pp}$.

Penguin paperback $\quad 0-14-016534-7 \quad \$ 10.00$ Available September 1992

\section{JULY'S PEOPLE}

\section{Nadine Gordimer}

$176 \mathrm{pp}$.

Penguin paperback

$$
\text { 0-14-006140-1 }
$$

$\$ 9.00$

\section{THE INDOOR BOY}

\section{Anthony Sher}

"The final days of apartheid are the setting for the salvation of Leon, a determinedly nonheroic South African exile, in this ambitious third novel from South-African born actor and writer Sher." -Kirkus Reviews. 272 pp.

Viking hardcover $\quad 0-670-84456-X \quad \$ 20.00$

\section{ANCESTRAL VOICES}

\section{Etienne van Heerden}

Winner of 10 literary awards in his native South Africa, van Heerden is "the brightest light in the firmament of younger Afrikaans writers and... an eloquent witness of this moment of profound social change in the country."-André Brink. 272 pp.

Viking hardcover $\quad 0-670-82831-9 \quad \$ 21.00$

\section{THE WHITE RHINO HOTEL}

\section{Bartle Bull}

'Exposing the cruelty behind European settlers' self-styled civilizing missions in Africa, Bull's robust, old-fashioned adventure features a motley band of colorful characters in the hills of central Kenya in the years after WW I."-Publishers Weekly. Illustrations, endpaper map. $416 \mathrm{pp}$.

Viking hardcover $\quad \mathbf{0 - 6 7 0 - 8 3 9 9 8 - 1 \quad \$ 2 4 . 0 0}$
BATTLE FOR THE ELEPHANTS

Iain and Oria Douglas-Hamilton

"Exciting and well-written, a superb book....This chronicle of the fight for an ivory ban should be read by everyone concerned with conservation."-George P. Schaller, Wildlife Conservation International. Photographs. $416 \mathrm{pp}$.

Viking hardcover $\quad 0-670-84003-3 \quad \$ 30.00$

\section{SAFARI: A Chronicle of Adventure \\ Bartle Bull}

"Bull's interest lies in the people who were bewitched by Africa before him....Add to this a literate text, wonderful photos, maps, color illustrations, old movie posters and stills, and you have... a superlative book." - Field and Stream. 383 pp.

Penguin paperback $\quad 0-14-016885-0 \quad \$ 25.00$

\section{NONFICTION}

\section{NINE FACES OF KENYA}

Edited with an Introduction

\section{by Elspeth Huxley}

"A colorful mosaic depicting Kenya's swirling diversity" (Booklist), featuring contributions from such writers as Ernest Hemingway, Shiva Naipaul, Laurens Van Der Post, Richard Leakey, and Huxley herself. $480 \mathrm{pp}$.

Penguin paperback $\quad 0-14-014985-6 \quad \$ 12.00$

\section{DREAMED OF AFRICA}

\section{Kuki Gallmann}

"In a haunting memoir vividly reminiscent of Isak Dinesen and in the settler tradition of Beryl Markham and Elspeth Huxley, Ms. Gallmann captures perfectly the magic of Kenya." - The New York Times Book Review. Photographs. 336 pp. Penguin paperback $\quad 0-14-017102-9 \quad \$ 12.00$ 


\section{RESEARCHIN \\ AFRICAN \\ LITERATURES}

\section{EDITOR:}

Richard Bjornson

\section{SINGLE ISSUE:}

Individual, $\$ 10.00$

Institution, $\$ 20.00$

Postage, $\$ 1.75$ per issue

SUBSCRIPTION:

(4 issues)

Individual, $\$ 30.00$

Institution, $\$ 57.50$

Foreign surface post, $\$ 10.00$

\section{SEND ORDERS TO:}

Indiana University Press

Journals Division

601 N. Morton Street

Bloomington, IN 47404

Phone: 812-855-9449

Fax: 812-855-7931

\section{NORTH AFRICAN LITERATURES}

(Volume 23, Number 2)

Jean Dejeux: Francophone Literature in the Maghreb

Marc Gontard: Francophone North African Literature

Marie-Blanche Tahon: Women Novelists and Women in the Struggle for Algeria's National Liberation

François Desplanques: The Long, Luminous Wake of Mohammed Dib

Hafid Gafaita: Rachid Boudjedra: The Bard of Modernity

Anne Roche: Women's Literature in Algetia

M'hamed Alaoui Abdalaoui: The Moroccan Novel in French

Tahar Bekri: On FrenchLanguage Tunisian Literature

Tahar Djaout: Black "Beur" Writing

Charles Bonn: Kateb Yacine

Noureddine Bousfiha:

Contemporary FrenchLanguage Moroccan Poetry

And more 


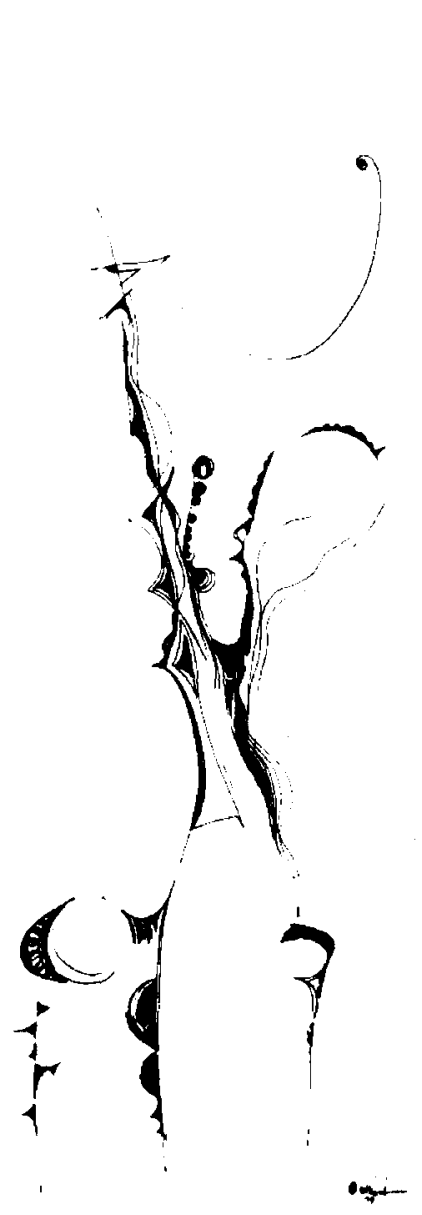

African Folktales in the New World William Bascom

Foreword by Alan Dundes

These essays, devoted to traditional narratives found in Africa and in the New World, represent the last major research project of William Bascom (1912-1981), eminent authority on African art and folklore-a demonstration of the African roots of African American folktales. Folkloristics cloth $\$ 35.00$ paper $\$ 14.95$

\section{Modern Algeria}

The Origins and

Development of a Nation

John Ruedy

"[Ruedy] has skillfully

compressed over two thousand

years of Algerian history into a

smooth, fast-paced narrative

while at the same time

addressing all the major

questions concerning Algeria's

historical development. . . . a

tour de force."

-Julia Clancy-Smith

cloth $\$ 39.95$ paper $\$ 16.95$

\section{Yoruba Ritual}

Performers, Play, Agency

Margaret Thompson

Drewal

The Yoruba of Nigeria conceive of rituals as journeys-actual or virtual. Performed as a parade, masking display, or trance, the journey evokes the transformative experience of ritual participation. Yoruba Ritual is an original and provocative study of these practices. African Systems of

Thought $\bullet$ illustrated cloth $\$ 35.00$ paper $\$ 14.95$

\section{Yoruba Ritual}

\section{A Companion Video}

\section{Margaret Thompson}

Drewal

Segments of the performances analyzed in Yoruba Ritual, conveying their sounds, colors, and energy. Subtitles key the performances to chapters of the book. Ideal for classroom use. African Systems of Thought 30-minute VHS video $\$ 29.95$

\section{The Sons Of}

\section{Sheba's Race}

African-Americans and the Italo-Ethiopian War, 1935-1941

\section{William R. Scott}

"This is an excellent work ..."

-Robert L. Harris, Jr.

Scott illustrates the response to the Italo-Ethiopian War of people of color, who linked the Ethiopian struggle to their own battles against racism and imperialism. Aroused AfricanAmericans prayed, preached, and protested for Ethiopian rights to help save the world's last outpost of authentic black rule from white control. Blacks in the Diaspora Available December illustrated, cloth $\$ 42.50$

\section{African Cinema}

\section{Politics and Culture}

\section{Manthia Diawara}

". . Diawara is quite simply the best critic (in any language) currently writing on African cinema." - Robert Stam Drawing on political science, economics, history, and cultural studies, Diawara provides an insider's account of the development and current status of African cinema. Blacks in the Diaspora $\cdot$ illustrated cloth $\$ 29.95$ paper $\$ 10.95$

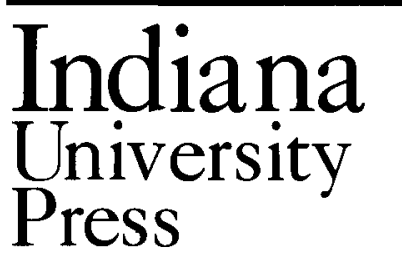

Dept A2RH Bloomington, IN 47404 At bookstores or 1-800-842-6796 


\section{Economic Growth in} South Africa

Selected Policy Issues

Edited by IRAJ ABEDIAN and

BARRY STANDISH, both at

University of Cape Town

This work gives a brief historical perspective, examines South Africa's macroeconomic policy and the country's physical and human resources. It shows what the authors believe to be the importance of the informal economy and income redistribution and the appropriate role for government.

1992256 pp.; 32 illus. paper $\$ 21.00$

\section{In My Father's House Africa in the Philosophy} of Culture

KWAME ANTHONY APPIAH, Harvard University

"An exceptional work, whose contextual sweep and lucidity provide a refreshing intellectual tone away from yahoo populism. In many profound ways, Kwame Appiah's In My Father's House ushers in a new level of discourse on race and culture, placing it within a universal narrative- and where else should it belong?... Without question, a first of its kind." -Wole Soyinka, from Race and the Rout of Reason

1992256 pp. $\$ 29.95$

\section{Going Green}

People, Politics and the

Environment in South Africa

Edited by JACKLYN COCK

University of the Witwatersrand, and

EDDIE KOCH, The Weekly Mail

Newspaper, Johannesburg

This book examines South Africa's environmental problems and shows how communities are rallying to the defense of the environment. Topics covered include land degradation, water pollution, urban ghettoes, and the industrial environment. In evaluating South Africa as a microcosm of First and Third World environmental problems, this book shows how the apartheid system has contributed to environmental damage, and offers possible solutions.

1992272 pp.; 75 illus. $\$ 29.95$
In a Time of Trouble

Law and Liberty in South

Africa's State of Emergency STEPHEN ELLMANN,

Columbia University Law'School

This work examines the intersection between law and emergency power in South Africa. Ellmann begins with an outline of the legal framework that exists in South Africa, pointing out the capacity it has to mitigate the excesses of the legislators' designs. He continues by demonstrating through the judges decisions that, with few exceptions, they repeatedly vindicated the emergency powers.

1992304 pp. $\$ 59.00$

\section{The Scattering Time Turkana Responses to Colonial Rule \\ JOHN LAMPHEAR, University of Texas, Austin}

The first full study of the pastoral Turkana people, this book explores their responses to European colonialism and examines the nature of their resistance, making extensive use of oral sources, as well as archival and published material. 1992336 pp.; 9 maps $\$ 72.00$

\section{Letters on West Africa and the Slave Trade} Paul Erdmann Isert's Journey to Guinea and the Caribbean Islands in Columbia (1788)

PAUL ERDMANN ISERT;

Edited and translated by SELENA AXELROD WINSNES

Isert's book, in the form of twelve letters evidently written for publication, has excited interest ever since it first appeared in 1788. Though Isert's text was long ago translated into other languages, this is its first translation from the original German into English.

1992288 pp.; 11 illus. $\$ 63.00$

Prices are subject to change and apply only in the U.S. To order, sent check or money order to: Social Sciences Marketing, Dept. KLH To order by phone using major credit cards please call 1-800-451-7556

Oxford University Press

200 Madison Avenue • New York, NY 10016 


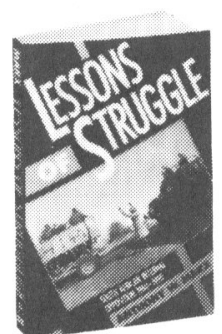

\section{Lessons of Struggle}

South African Internal Opposition, 1960-1990

ANTHONY W. MARX, Columbia University

“A richly textured and timely discussion of the peoples' movements during the years we spent on Robben Island and in exile. We are lucky to have such an insightful analyst."

-Walter Sisulu, African National Congress

"Engaged, balanced and resourceful scholarship...An insightful, historically grounded analysis of the character, strategies and prospects of South Africa's ascendant political opposi-

tion....Timely."-John A. Marcum, University of California

"One of the most revealing studies of South Africa in a decade."

-Henry Bienen, Princeton University

1992384 pp.; 13 illus. paper $\$ 15.95$ cloth $\$ 42.50$

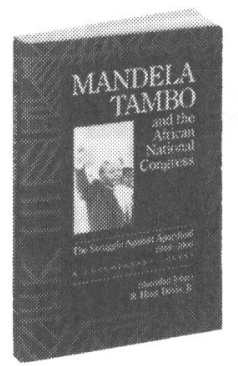

\section{Mandela, Tambo, and the African} National Congress

The Struggle Against Apartheid, 1948-1990, A Documentary Survey

Edited by SHERIDAN JOHNS, Duke University, and R. HUNT DAVIS, JR., University of Florida

"Timely and useful....Draws upon press statements, interviews, and speeches by...Nelson Mandela and Oliver Tambo, as well as upon documents issued by the ANC itself....Sheridan Johns and Hunt Davis are to be commended."-The International Journal of African Historical Studies

"A wonderful collection of speeches, texts, documents, and testimonials that capture the essence of liberation struggle in South Africa. A must."

-Nadar Entessar, Spring Hill College

1991376 pp.; 2 illus. paper $\$ 13.95$

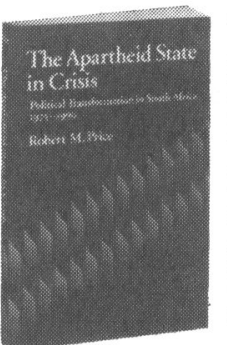

\section{The Apartheid State in Crisis}

Political Transformation of South Africa, 1975-1990

ROBERT M. PRICE, University of California, Berkeley

"Easily digestible synthesis of wisdom from dozens of the bestinformed observers of South Africa, seasoned with the author's own logical and jargon-free analytical framework....A welcome contribution."-Foreign Affairs

"A very impressive job of synthesis and analysis that makes a significant contribution to the current literature on South

Africa....It comes near to being 'the one book you should read if you want to understand South Africa today'."

- Gail Gerhart, Columbia University

1991328 pp.; 28 illus. paper $\$ 16.95$ cloth $\$ 55.00$

Prices are subject to change.

To request an examination copy, write on school letterhead giving

full course information, including course name, level,

expected enrollment, and your decision deadline, to

\section{Oxford University Press}

ATTN: College Sales Coordinator

200 Madison Avenue • New York, NY 10016 
This grants program is designed to assist in the professional re-establishment of talented African scholars who are returning from doctoral studies abroad and have a research interest in issues related to the revitalization and development of education in sub-Saharan Africa. All proposed projects must include an explicit and substantial focus on female school participation as part of the set of educational issues to be examined.

Applicants may submit research proposals prior to or within one year of returning to their Africa-based institutions. Grants are made to the scholar, but the proposal must be endorsed by the African institution where the applicant will be a full-time staff member. Also required are: two letters of recommendation from academic supervisors at the institution where the candidate carried out doctoral study; postgraduate transcripts; and a resume.

There are no deadlines for submission of proposals. For a full description of the program, write to:

Scholars on Education Re-Entry Program OR Scholars on Education Re-Entry Program The Rockefeller Foundation 1133 Avenue of the Americas The Rockefeller Foundation

New York, New York 10036 USA P.O. Box 47543 Nairobi, Kenya 


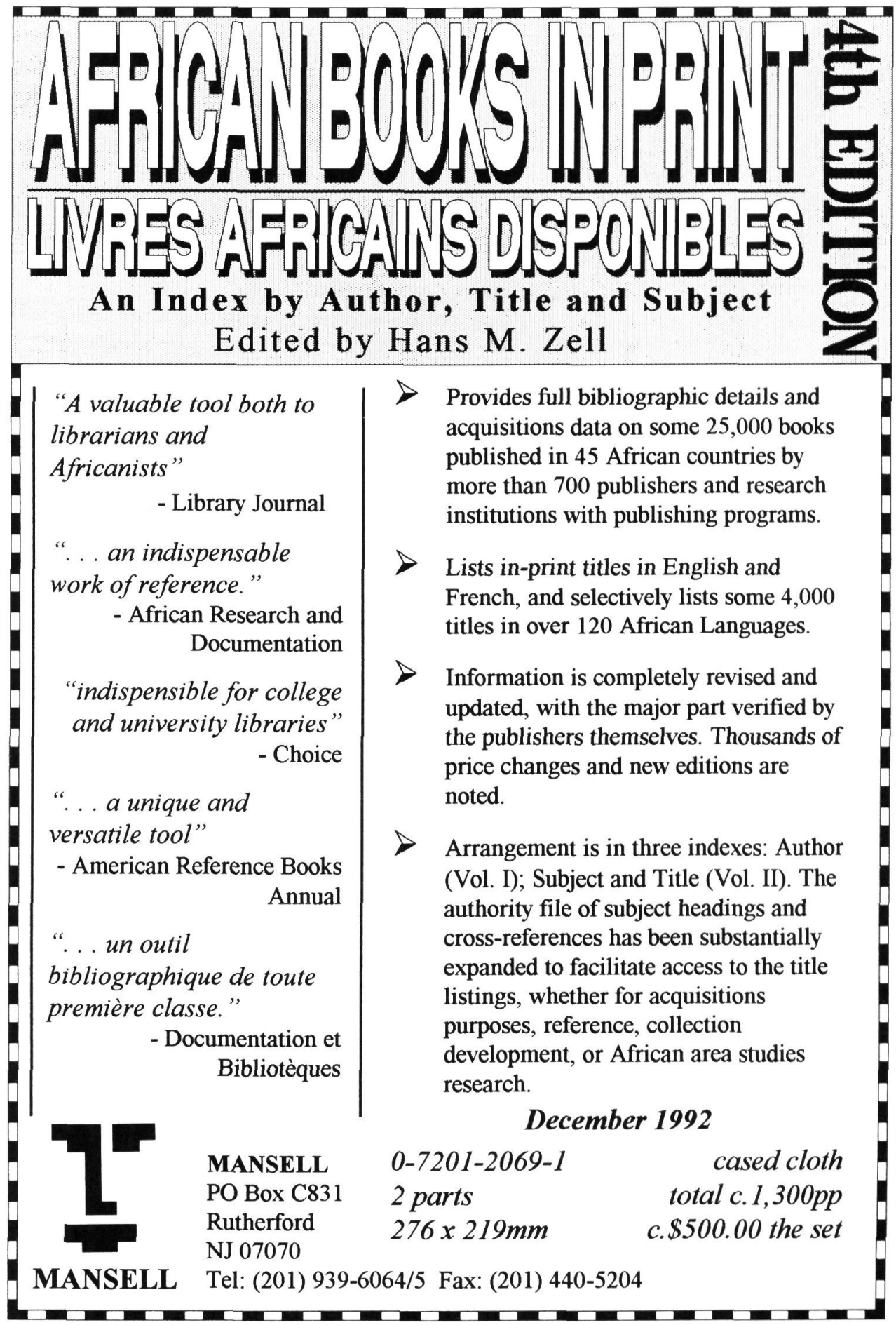


AFRICAN STUDIES ASSOCIATION

Credit Union Building

Emory University

Atlanta, GA 30322

Address Correction Requested

Non-Profit

U. S. Postage

PAID

Ann Arbor, MI

Permit No. 195 